Cletus C. Coughlin and Thomas B. Mandelbaum

Cletus C. Coughin is a senior economist and Thomas B. Mandelbaum is an economist at the Federal Reserve Bank of St. Louis.

Thomas A. Pollmann provided research assistance.

\title{
Why Have State Per Capita Incomes Diverged Recently?
}

$\mathbb{F}$ ences in per capita income across states narrowed substantially. By 1978, for example, one measure of state per capita income inequality had fallen to less than one-third of its 1932 value. Since 1978, however, this trend toward greater income equality across states has been sharply reversed; by 1987, state per capita income inequality had risen back to its 1966 level.

Historically, disparate regional income growth has generated political pressures to alter federal policies. For example, faster income growth in the South and West relative to the Northeast and Midwest in the 1970 s led to charges that these differential growth rates were due, in part, to the distribution of federal government expenditures. ${ }^{2}$ Yet, the Sun Belt-Frost Belt controversy arose during a period in which state per capita income growth was converging. Pressures for increased federal action in the realms of farm policy, trade policy and industrial targeting are even more likely to appear because of the increasing income divergence across states in the $1980 \mathrm{~s}^{2}$

This study pursues two objectives. First, it identifies the specific states responsible for the increasing inequality of state per capita income. Second, it examines whether well-known descriptions of regional growth and major economic changes can explain this new phenomenon.

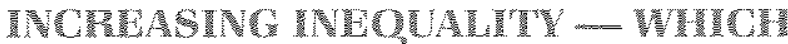 GTATS ANE DIVIRENG?}

The recent sharp reversal of the 45-year trend toward lesse: state per capita income inequality is shown in chart 1.3 The measure of income inequality across states used in the chart is the annual coefficient of variation of state per capita income; its precise calculation is detailed on page 28 . Income inequality across states generally declined from 1932 to 1978 ; since then, it has risen gradu-

For example, see "The Second War Between the States" (1977) and "Federal Spending: The Northeast's Loss is the Sunbelt's Gain" (1976).

2Different views of the appropriate federal role can be found in Reich (1988) and Weinstein and Gross (1988).

The reversal of the income inequality trend was confirmed statistically by regressing state per capita income inequality on time. To allow for the possibility of a structural break in 1978, a piecewise linear regression model was estimated. The results, based on conventional hypotheses tests, indicated a negative relationship between inequality and time until 1978 and $a$ positive relationship thereafter. 


\section{Chart 1}

\section{Inequality of State Per Capita Income}

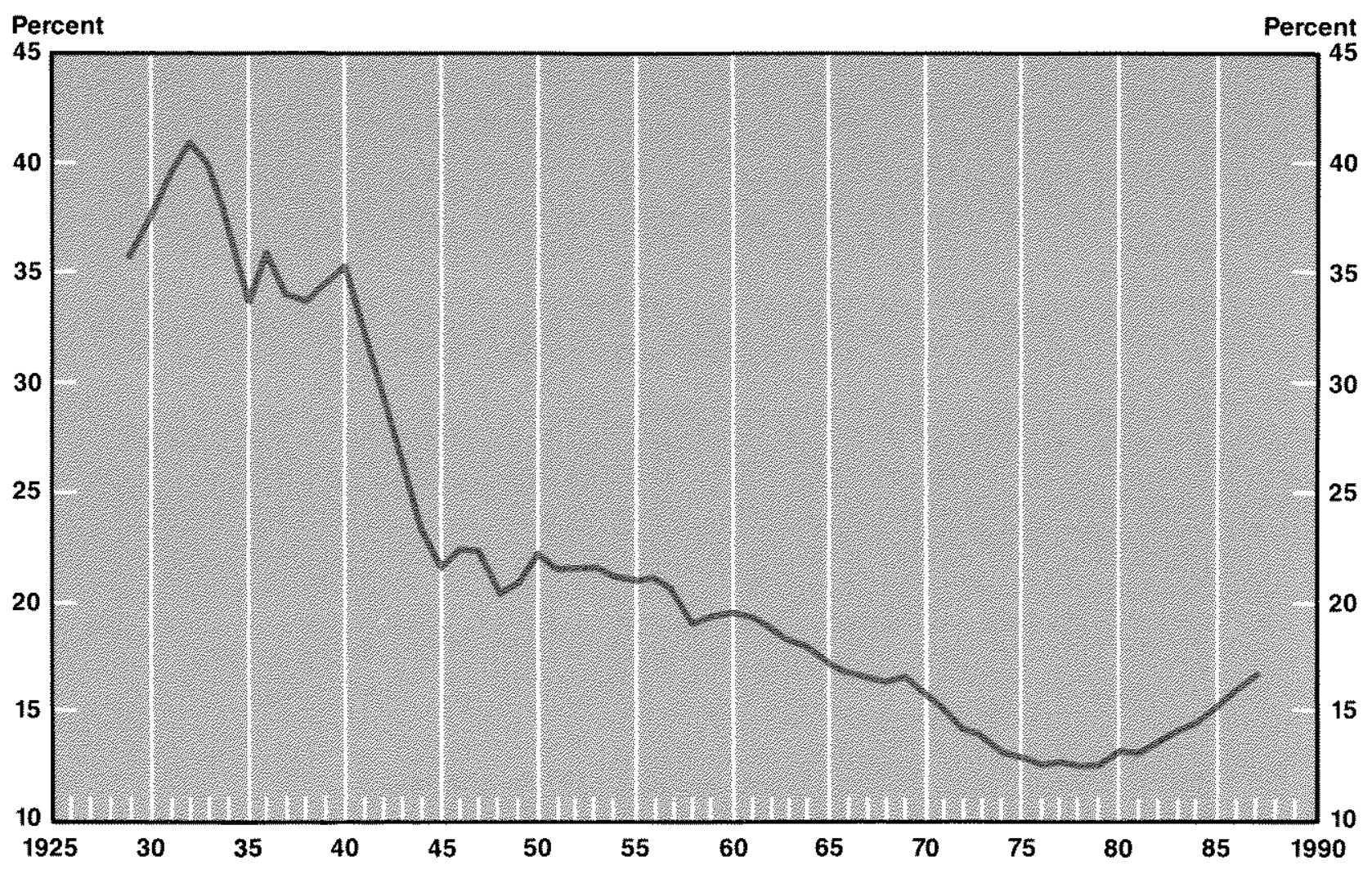

ally, but consistently. By 1987, it had climbed back to its mid-1960s levels."

Differential income growth across states has two opposing effects on state per capita income inequality measures. Income inequality is reduced when states whose per capita incomes exceed lare less than the average for all states experience slower (faster) than average growth in income. Similarly, income inequality rises when states whose per capita incomes exceed (are less than) the average for all states experience faster (slower) than average income growth. The net effect on income inequality depends on which of these two possible growth patterns predominate. As chart 1 indicates, the former pattem predominated until the end of the 1970 s, but the latter result has oc* curred sinee then.

Table 1 identifies the impact of each state on income inequality since 1978 . The analysis in this table, and throughout the article, focuses on the state's relative per capita income - the state's per capita income expressed as a percent of the per capita income of all (continental) states. For example, if Mississippi's per capita income in 1978 was thee-fourths of the average per capita income of all states for that year, its relative per capita in-

4Personal income consists of labor and proprietor income, dividends, interest, rent and transfer payments. Transfer poyments differ from the other components in that they are not derived from current economic activity. The interstate inequality of per capita income minus transfers followed similar trends as the irequality of total per capita income; the coefficient of variation of non-transfer per capita income tor the 48 states frended downward from 23.3 percent in 1946 to a minimum of 13.8 percert in 1976, then rose to 19.1 percent by 1987 . 
Table 1

\section{Classification of States Based on Per Capita Income Levels and Changes}

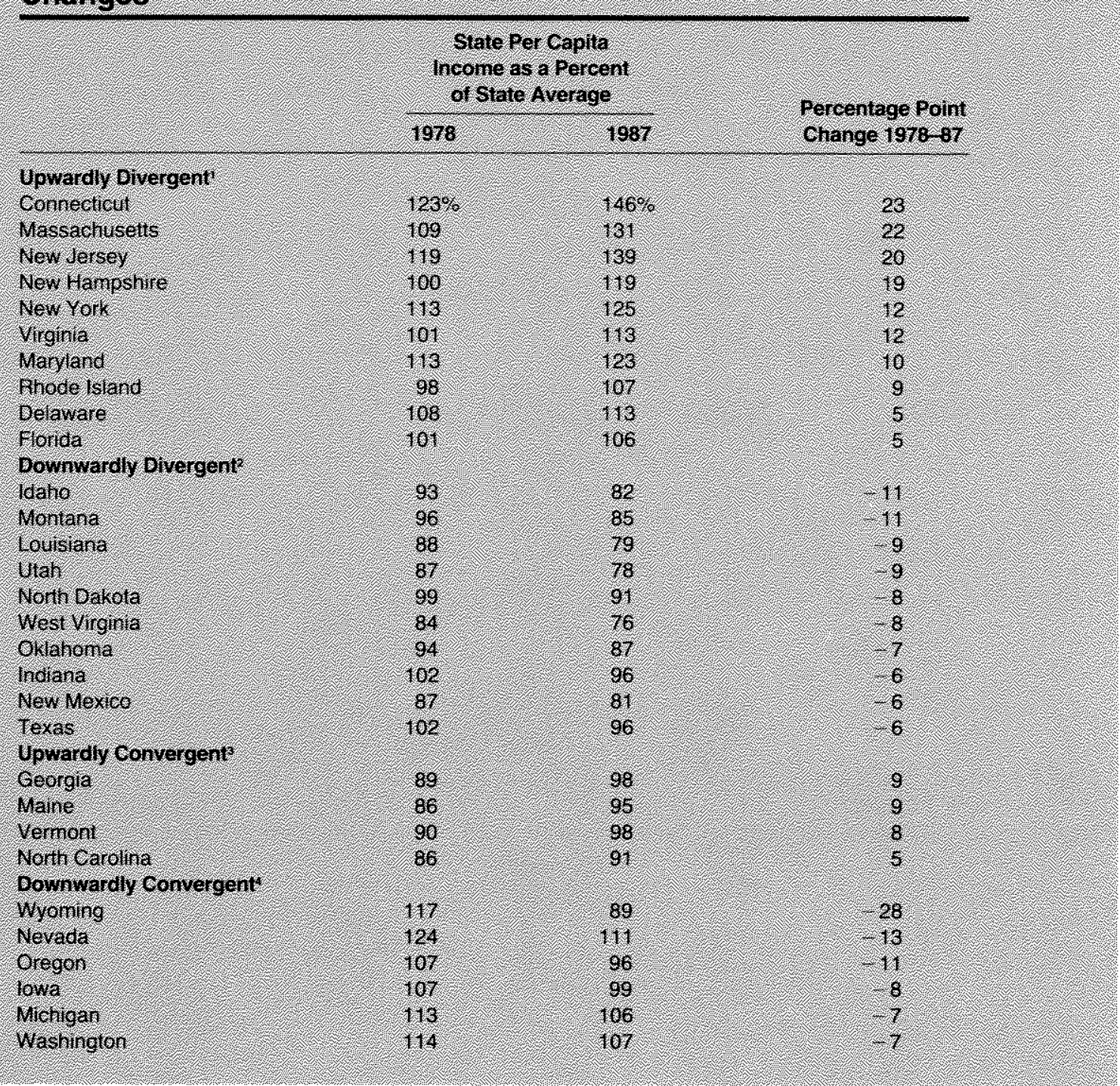

come for 1978 would equal 75 percent. A state is judged to have had an impact on income inequality if its relative per capita income changed by 5 percentage points or more between 1978 and 1987.

The income changes of 20 states tended to increase inequality. Ten states with above-average per capita income in 1978 - Connecticut, Massachusetts, New Jersey, New Hampshire, New York, Virginia, Maryland, Rhode Island, Delaware and Florida - experienced substantially faster growth between 1978 and 1987 than the average. We call these states "upwardly divergent," There were 10 states with below-average per capita income -
Idaho, Montana, Louisiana, Utah, North Dakota, West Virginia, Oklahoma, Indiana, New Mexico and Texas - that experienced substantially slower than the average growth. We call these states "downwardly divergent."

We have also identified 10 states whose income changes have tended to reduce inequality. Four of them - Georgia, Maine, Vermont and North Carolina - were states whose per capita incomes were below the average across states in 1978 , but who have grown faster than this average since then. These states are called "upwardly convergent." 
Table 1 cont'd.

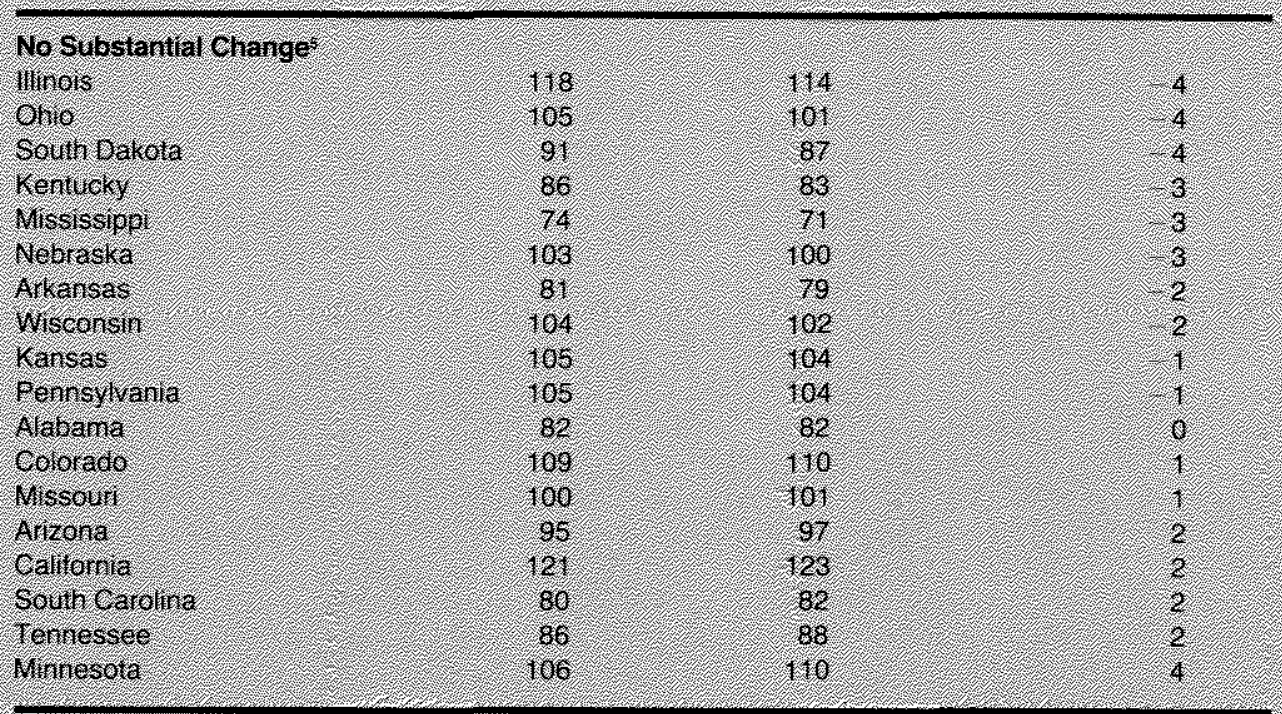

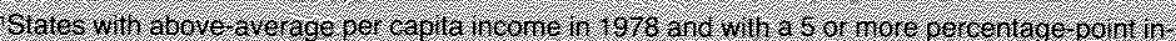

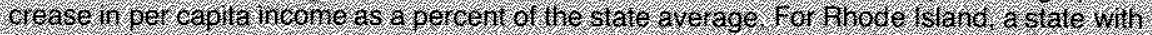

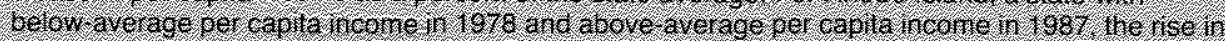

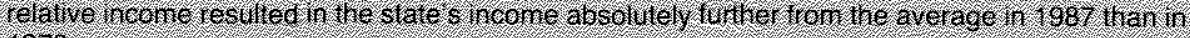
1978.

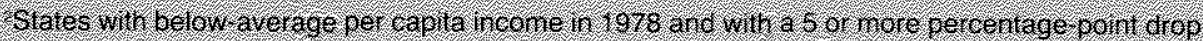

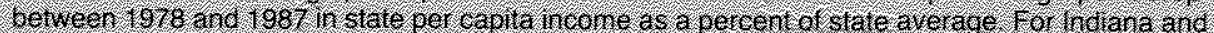

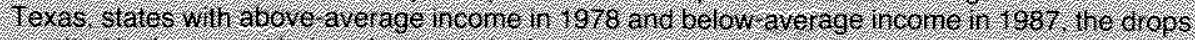

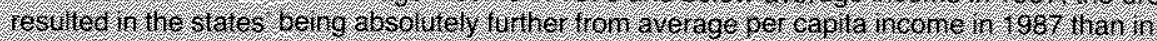
1978.

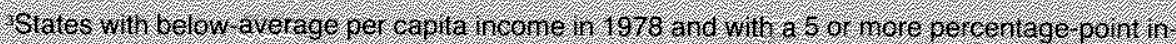

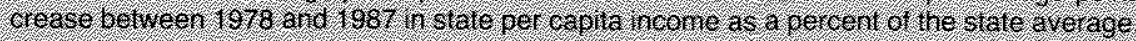

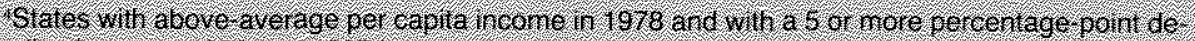

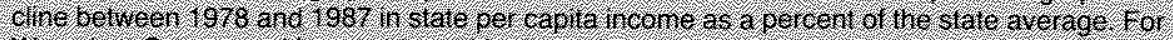

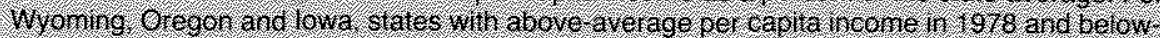

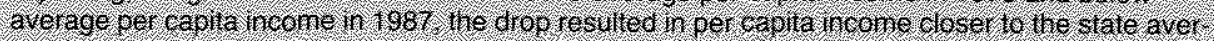
29. in 198 . than in 1978 .

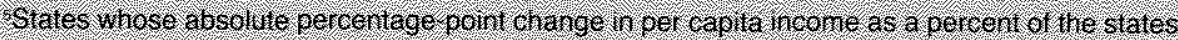
Was less han 5 percent beheen 1978 a 19 108

Six states - Wyoming, Nevada, Oregon, Iowa, Michigan and Washington - were "downwardly convergent." These states, whose per capita incomes exceeded the average across states in 1978 , but who have grown slower than this average, also contributed to reduced inequality. Of all the states, Wyoming is the hardest to categorize. Between 1978 and 1987 , it experienced the largest percentage point decline in relative per capita income of the 48 states. This 28 -point decline dropped Wyoming from an above-average income level in 1978 to below-average by 1987 . If the analysis had focused on changes from 1984 to 1987 , Wyoming would have been labeled as downwardly divergent rather than downwardly convergent.

Finally, 18 states had relative per capita incomes that changed less than 5 percentage points be- tween 1978 and 1987 . These states had little impact on the recent changes in inequality.

To provide a geographic overview of the results presented in table 1 , a map is presented. As the map reveals, states experiencing relatively rapid per capita income growth are, without exception, Atlantic Coast states. Since these states tend to have per capita incomes above the average across states, their rapid growth tends to contribute to increasing inequality. On the other hand, states experiencing relatively slow per capita income growth are scattered across the remainder of the continental United States. The following analysis examines some of the popular descriptions of regional growth and some major economic changes to see if they can explain this rising inequality. 


\section{Measuring Income Inequality}

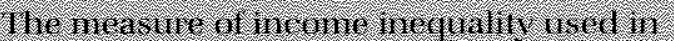
this antielo is the evefficient of timation of an.

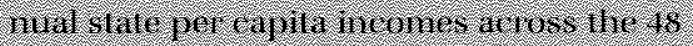

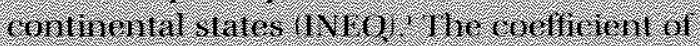

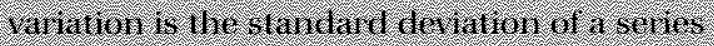

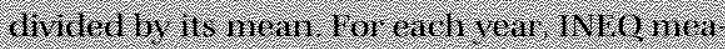
sures the degree of dispersion of state pet teap ita incomes aboni ire nean slate jer eapita incone MI AN, With eirh state Weighted equall. MIIN is tallinated as follows:

$$
\text { Mrin }=\frac{1}{2} \operatorname{sich} 48
$$

Where $=$ stibscripl denoung the indivgduat States and SPCI = state per capila income.

This, he INIa is calcitated as follows:

$$
\begin{aligned}
& 48
\end{aligned}
$$

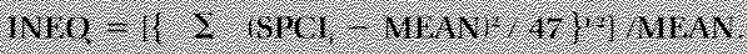

$$
\begin{aligned}
& i=1
\end{aligned}
$$

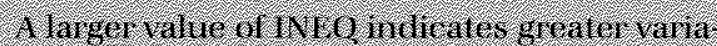
firmbletween stafe por taputa incones and. 1his greater inequality: II per capita incomes

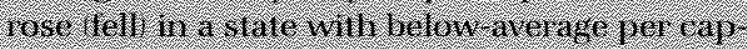

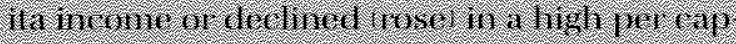

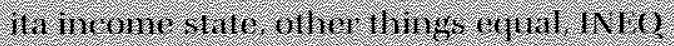

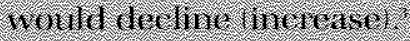

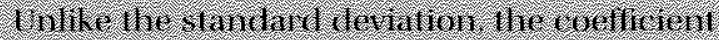

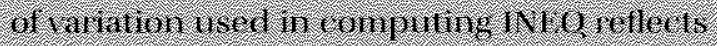

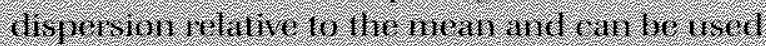
14. fents wilh differing nieans lor example. If per. eopila interite in each strie anibled betwer.

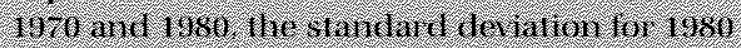

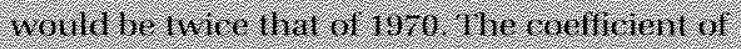
tarintion, howeren twould show no change sinie if ts standardized ty dho nean per cumili intome:

for the coelficient of vartaton lo be an mibi issed measure of mequaliv, the inderlving data mist lie normally distributed I Ismy the shapirollitk 1965) statistie, he state per capina imome series was tested for mormaliny tor each. veat. The null hy wothes is, that the stare per

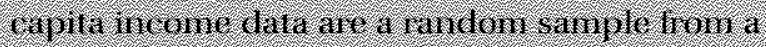
nomal destribinim, fonld not bie rejected at the 5 percent level ton any vears in the postwat period.

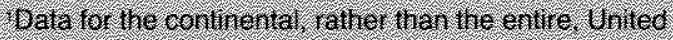

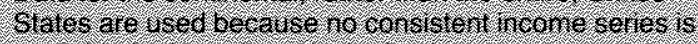
avalable for l tawell or Alaska dor he poswar period

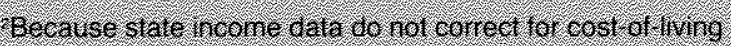

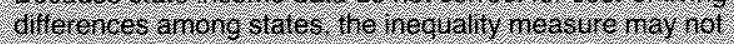

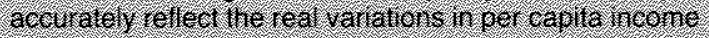
levels anorg states. Nor refrable state costor living data

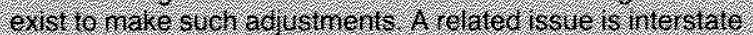

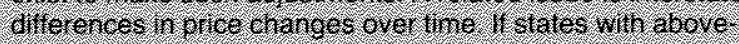

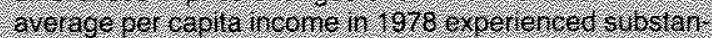

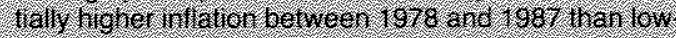

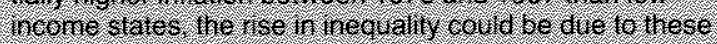

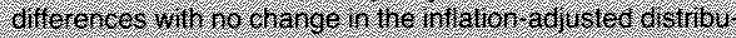

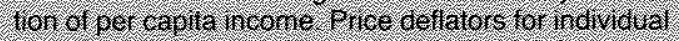

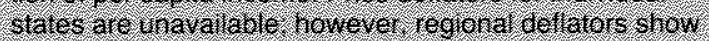
inte difererce in hintion beween 1978 and 1987 . Using a

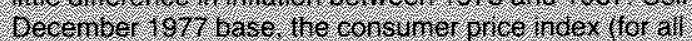

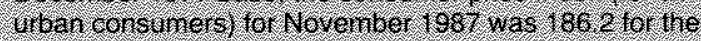

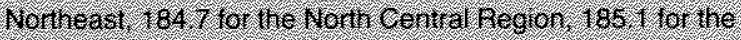
Soitrand 167 t tor tre West

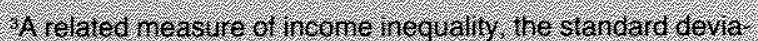

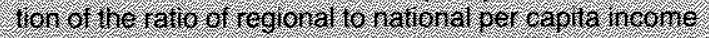

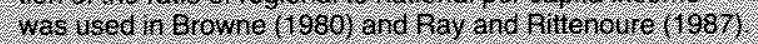

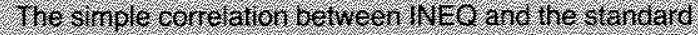

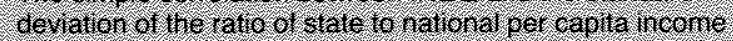

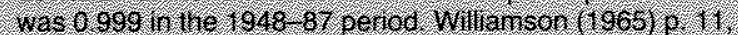

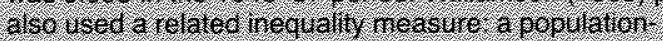

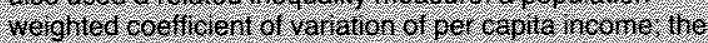

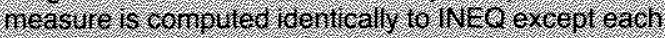

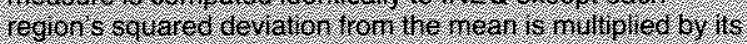

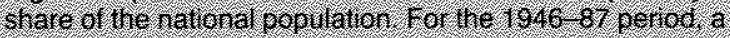

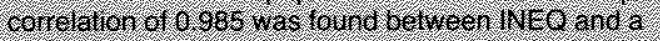

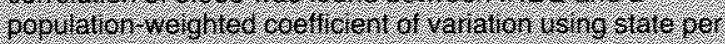
casts incone

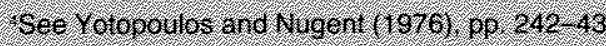

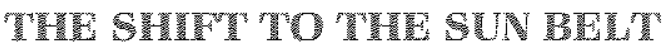

The shift of industrial activity from the nation's Frost Belt to the Sun Belt contributed to the less ened inequality during the 1970s. Businesses, particularly manufacturing, migrated to the Sun Belt from the Frost Belt for various reasons, including lower wage rates. ${ }^{5}$ Since manufacturing wages are

sSee Crandal (1986), pp. 124-27, for a briel survey of empirical research documenting and explaining marufacturing's shift to the Sun Belt. 


\section{States Classified by $\mathbf{1 9 7 8 - 8 7}$ Per Capita Income Change}

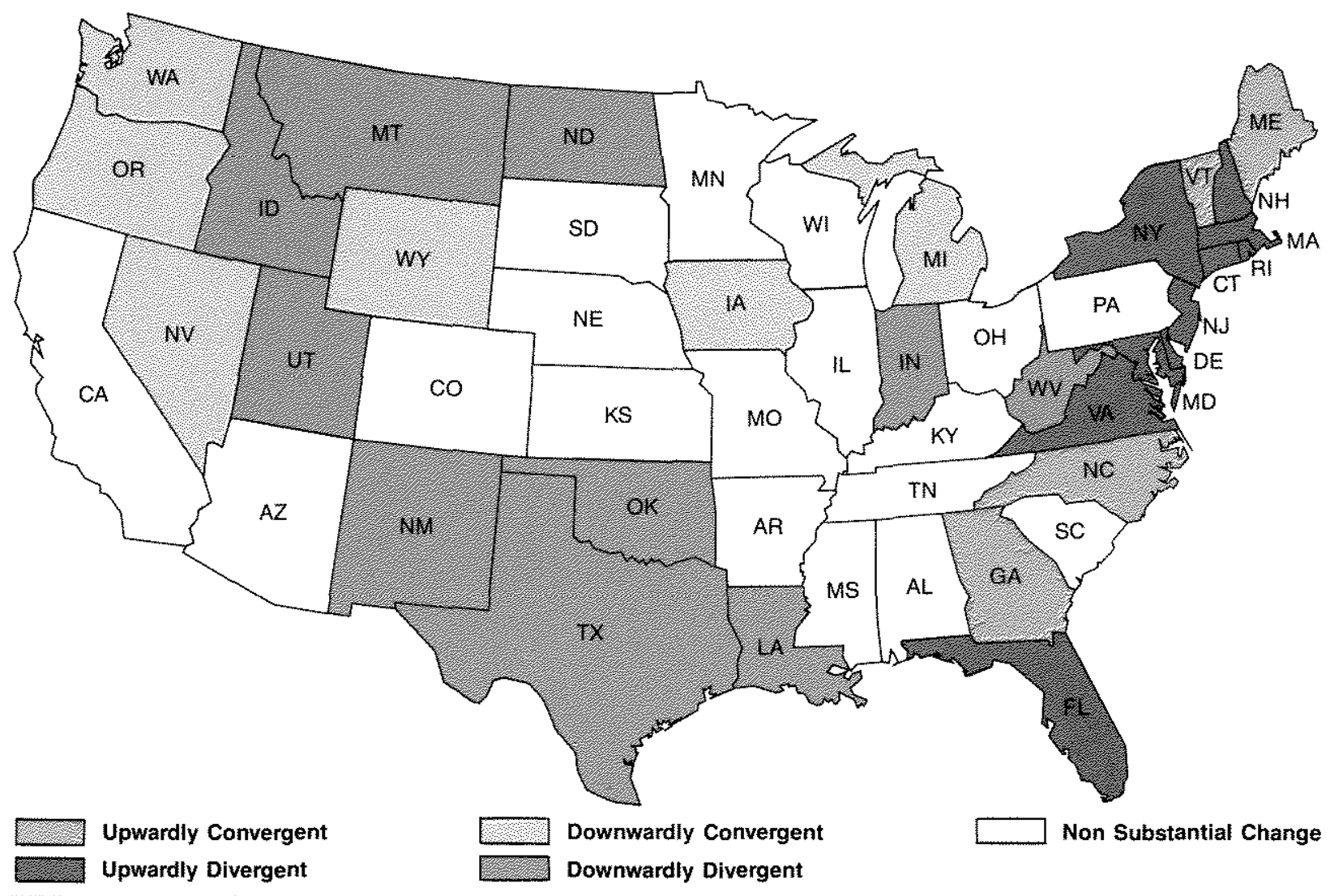

well above the average wage of all industries in all regions of the nation, this shift of labor demand from higher'wage to lowerwage states produced higher relative growth in per capita income in the lower-income states and relatively lower income growth in the higher income states. For example, using one listing of Frost Belt and Sun Belt states (see lable 2 ), the Sun Belt's share of (continental) U.S. manufacturing employment increased from 34.4 percent in 1969 to 39.0 percent in 1978 , while the Frost Belt's share docreased from 51.3 percent to 46.2 percent. During the same period, average relative per capila income for the sun Bell states increased from 91,2 percent in 1969 to 92.6 percent in 1978; in the Frost Belt states, it fell from 112.4 percent in 1969 to 106.3 percent in 1978.

This shift has continued in the last 10 years. The Sun Belt's share of manufacturing emplovment increased from 39.0 percent in 1978 to 43.7 percent in 1987, while the Frost Belt's share decreased from 462 percent to 41.1 percent. Although the shift, by itself, tends to reduce income inequality, the actual per capita incomes for the two regions have not continued to converge over this period. White the average per capita income for the Sun Belt states as a percentage of the average income for all states rose slightly from 92.6 percent to 93.1 percent between 1978 and 1987 , it jumped from 106.3 percent to 111.1 percent in the frost Belt states.

One reason why per capita incomes in the Frost Belt and the Sun Belt have stopped converging since 1978 is that the shift of manufacturing activity to the sun Belt is less widespread than in previous decades; since 1978, manufacturing trends in many states differed sharply from that of their region. For example, the Frost Belt's share of manufacturing workers continued to decline after 
Table 2

Impact of Sun Belt and Frost Belt States on Inequality

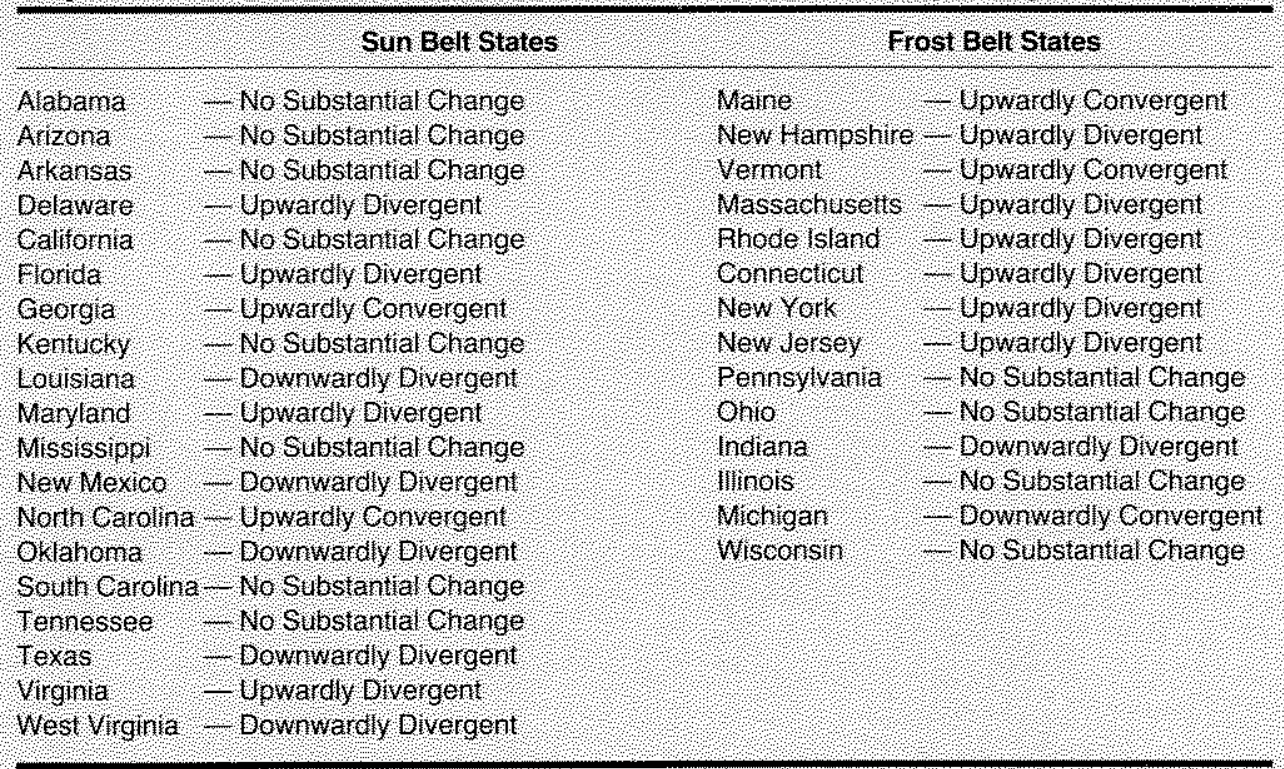

SOURCE Weinstein Gross and Rees (1985) and able 1

1978, but manutacturing in most New England states grew as fast as, or faster than, the nation. Manufacturing job shares remained constant between 1978 and 1987 in Maine, Massachusetts and Connecticut, while rising in New fampshire and Vemont. The rapid growth of high-technology manufacturing between 1978 and 1984 , particulary computer- and defense-related production, was largely responsible for the rapid growth of per capita income in New England. This growth contributed to the Frost Belt's relatively rapid income growth and the nation's increasing income inequality since 1978. As table 2 shows, the higher' income states of Connecticut, New Hampshire and Massachuset ts are classified as upwardy divergent

Despite a shapp loss of manufacturing jobs since 1978, New York, New Jersey and Rhode Island have had relatively rapid per capita income growth, contributing to the rising inequality. In these states, rapid income growth was fueled by the expansion of construction and services, especially health, business and financial services.

At the same time, some sun Belt states have not shared in that region's industrial expansion. Manufacturing employment from 1978 to 1987 grew substantially slower in West Virginia and Louisiand and no faster in Kentucky, Maryland, Oklahoma and Tennessee than it did in the nation. The slower growth in these states may have stemmed, in part, from their specialization in energy-related industries, an issue discussed later in this article. As table 2 indicates, Louisiana, Oklahoma and West Virginia were among the downwardly divergent Sun Belt states.

To summarize, manufacturing activity has continued to shift from the Frost Belt to the Sun Belt states in the $1980 \mathrm{~s}$, but not as widely as in previous decades; in fact, a number of states in both

\footnotetext{
'See Bradbury and Browne (1988). Manufacturing, however, was not entirely responsible tor New England's per capita income growth, especially since 1985 . Rapid growth of earnings in construction and in service-producing industries lespecially finance, insurance, real estate, medical and business services) combined with relatively slow population growth to spur New England's expansion.
}

sU.S. Department of Commerce (1987), p. 2, and Ray and Rittenoure (1987) p. 244, briefly discuss sources of growth in
Mid-Allantic Stazes. Gross and Weinstein (1988) argue that the fapid growth of the New Englard ard Mid-Atantic economies in the 1980 s is at least partially due to a rise in federal spending in those regions, particularly grantsminat and procurement. The slower economic growth of some Sun Belt states, meanwhile, allegedly stems from a decline in the federal expenditures they receive. 
"belts" have experienced manufacturing growth counter to that of their region as a whole. Thus, rather than continuing to converge as they had in the early and middle 1970s, the gap between per capita incomes in the Frost Belt and Sun Belt states has widened since 1978 .

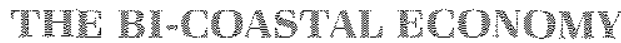

According to a study released in 1986 by the Democratic staff of the Joint Economic Committee of the U.S. Congress, national economic growth between 1981 and 1985 was concentrated in states on the East Coast and in Califomia." The rapid expansion of these states relative to the nation's interion states led to the characterization of the United States as a bi-coastal economy, despite the absence of Oregon and Washington from the list of fast-growing states. For example, the study noted that real earnings grew at a 4 percent rate in the coastal states during the $1981-85$ period, compared with a 1.4 percent rate in the non-coastal states.

Does the bi-coastal economy, which is primarily a description rather than an explanation of the pattern of growth, provide insights into the increasing inequality of state per capita income? Two questions must be answered affimatively. First, are the bi-coastal states experiencing more rapid growth of per capita income? The answer to this question is "yes." Table 3 lists the bi-coastal states and their per capita income perfomance for $1978-87$. Of the 16 bi-coastal states, 14 grew substantially faster in per apita income than average California, the sole West Coast state, and South Carolina experienced no substantial change in their relative per capita income growth.

Second, did these rapidly growing states also have above-average per capita incomes? If so, the rapid growth causes their per capita iroome to rise further above the average, thus, inereasing state income inequality. of the 14 states with rapidly growing per capta income, 10 are classified as

\section{Table 3}

Impact of Bi-Coastal States on Inequality

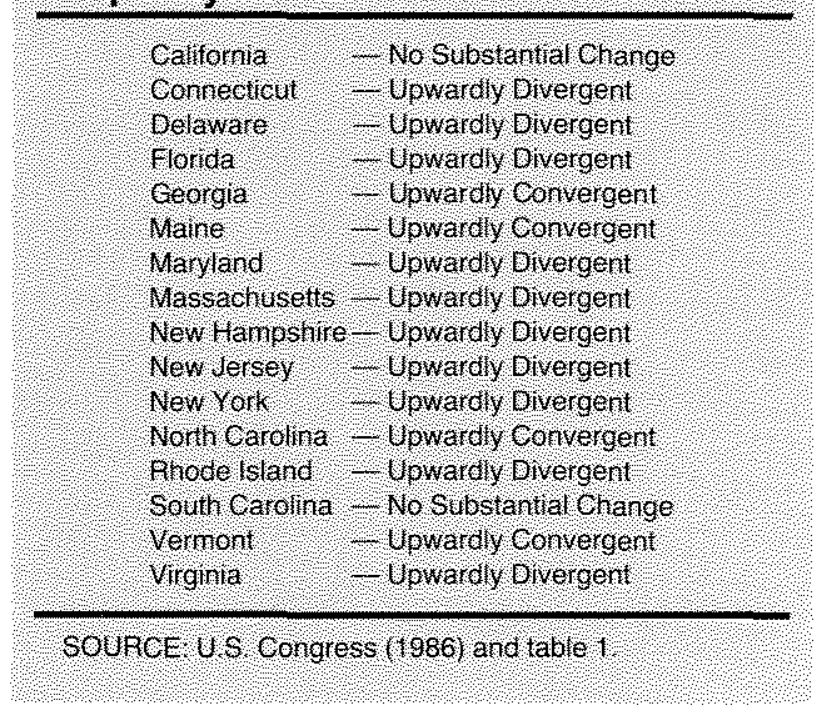

divergent; only four of these states are comvergent In fact, the 10 divergent states account for all the upwardly divergent states in the continental United States and the four convergent states account for all the upwardly convergent states. Thus, relatively rapid East Coast income growth was a primay influence in horeasing the inequality of state per capita income.

While explanations for the relatively rapid growth of income in the coastal states are speculative, explanations of why income growth in interior states lagged behind are more precise. "Falling energy prices and the agricultural crisis are two frequently cited reasons for the below-average performance.

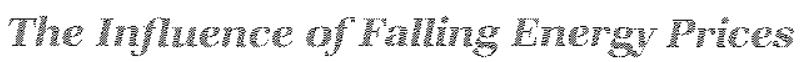

The economic growth of states endowed with substantial energy resources tends to be directly related to energy prices, while the economic
The study, The Bi-Coastal Economy, was released in July 1986 by the Joint Economic Committee of the U.S. Congress. See U.S. Congress (1986).

so The Joint Economic Committee study suggested a number of reasons for the uneven pattern of regional growth during the first half of the 1980s. The study suggests that "a central cause is trade and the current massive imbalance in trade that exists between the United States and its trading partners" that disproportionately affects interior states. U.S. exports of both agricultural and nonagricultural commodities had declined to some extent, according to the authors, because of increased competition from Third World nations attempting to earn foreign cur- rency to pay interest on their loans. Also, increased compelition from imported manufactured goods in domestic markets was clamed to be partially responsible for the observed pattern of regional growth. The study's finat explanation relates to the strong job growth in the service industry, particularly in firms engaged in importing, advertising, financing and selling foreignmade goods. Such industries are strongly concentrated on the coasts, according to the study, and their growth helped boost the coastal states. 


\section{Chart 2}

\section{Relative Energy Prices and Relative Per Capita Income in Energy and Non-Energy States}

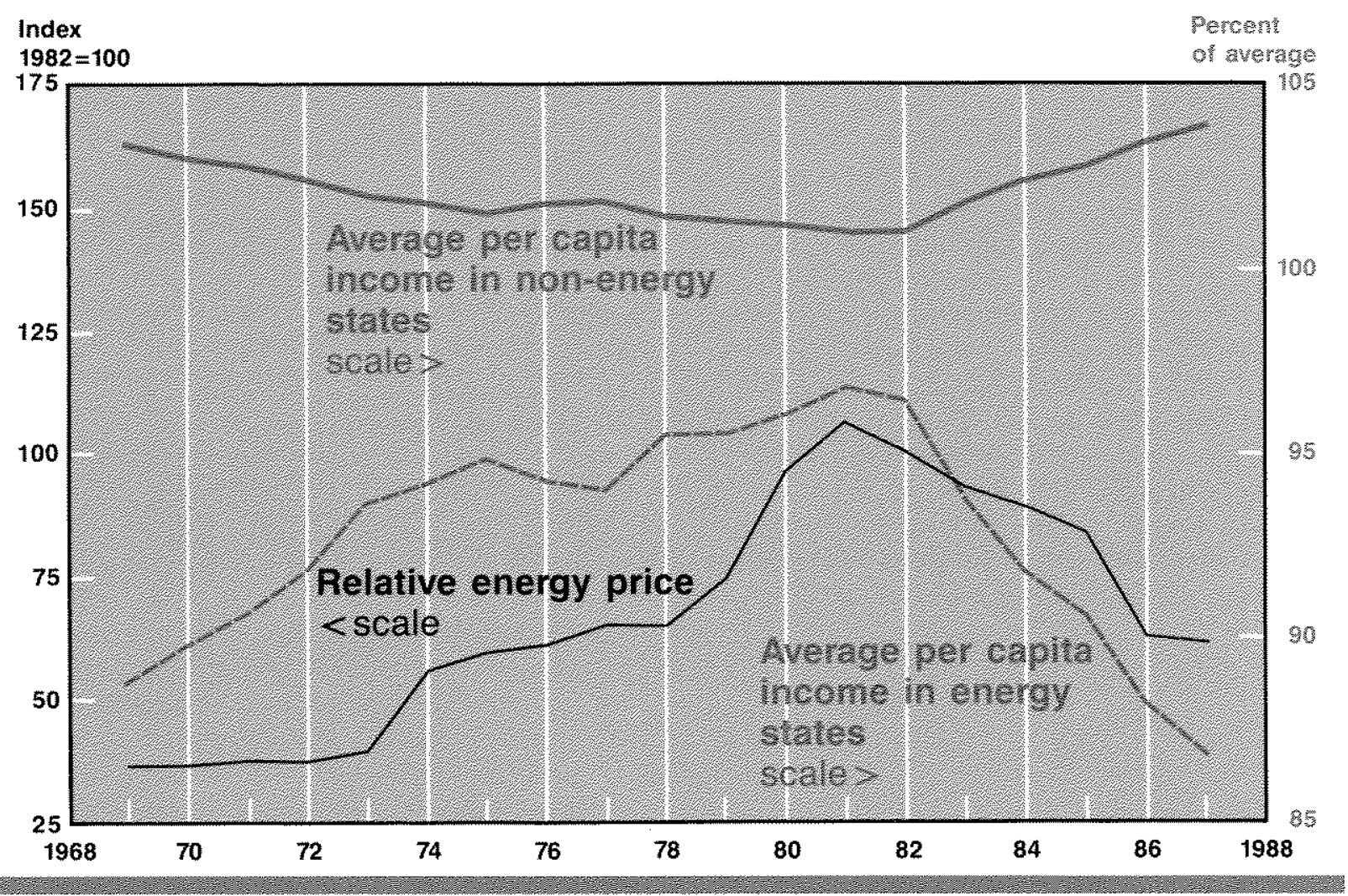

growth of energy-poor states tends to be inversely related." As chart 2 shows, energy prices relative to the general price level rose rapidly from 1973 , peaked in 1981, then fell through $1987 .^{2}$ If energyrich states are also generally lower-income states, the decline in energy prices in the 1980 s has contributed to the increasing interstate inequality by slowing income growth in these states relative to those that purchase most of their energy re* sources from out-of-state sources.

The evidence supports this explanation. As chart 2 shows, relative per capita income in energy states generally followed the rise and fall of energy prices, while the relationship was an inverse one
${ }^{\dagger}$ See Manuel (1982) and Brown and Hill (1987) for empirical studies documenting the relationship between energy prices and state economic growth. Miernyk (1977) and Manuel (1982) discuss why energy prices and state economic growth are linked. As they rise, energy costs become an increasingly important factor in determining where to locate an energyintensive industry. Such relocation tends to shitt employment opportunities from energy-poor regions to energy-producing states. Higher energy prices may also stimulate greater investment in energy production and exploration, increasing jobs in energy-producing states. Athough profits from relocating manufacturing firms are likely to be distributed to owners throughout the nation, the increased employment tends to increase income in energy-producing states. In contrast, energy-poor states are burdened with higher costs for fuel and inputs in which energy costs are an important component. When energy prices fall, the advantages shitt to states that heavily import ofl rather than produce it.

\begin{abstract}
${ }^{12}$ Relative energy prices in this article are indicated by the producer price index for fuels, related products and electric power divided by the GNP implicit price deflator for the private business sector. The oil embargo in 1973-74 contributed directly to the price increases for petroleum and indirectly to price in creases for other energy sources as energy users searched for oil substitutes. Relaxation of price controls during the period contributed to the price increases of natural gas. The easing of energy prices in the current decade reflects a worldwide increase in global oil supplies as international oil cartels are unable to agree on production quotas. Also, heavy investment to increase enefgy efficiency by car makers, businesses and households has caused the quartity of energy demanded to grow substantially stower than the rest of the nation's economy, according to Schmidt (1988).
\end{abstract}




\section{Table 4 \\ Impact of Energy-Producing States on Inequality}

Wyoming - Dowrivardy Convergen

West Vrgina. Dowrwardy D vergen

Oklahoma? Dowhwarly Djergent

Loulsiana V Downuardj bivergent

Kenluky ? No Substanial change

Texas : $\checkmark$ Oow wardy Duvergent

North Dakda - Downwardy Duergent

Hew Hexico - Dowmardy Divergent

Colorado: No Substantial Change

Montana ? : Downerdly Qvergent

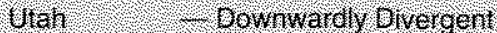

NOIE. Ehergy producing states are those in which earh ings rom ol and gas extraction and co bl winthe jroduced at loast 3 pereent or libe states total eamings in 1981 states are ordered fron those With the highest to the lowest ber centago:

SOURCE rable

for the other states." Table 4 lists the 11 energy states in the continental U.S. in which earnings from oil and gas extraction and coal mining produced at least 3 percent of the state's total eamings in 1981, the year in which energy prices peaked and oil and gas extraction and coal mining provided its largest share of total U.S. eamings in the postwar period." The energy states are listed in descending order according to the propotion of their earnings derived from oll and gas extractions and coal mining, ranging from Wyoming with 18.6 percent to Utah with 3.1 percent.

In 1969, before the shap rise in energy prices. per capita income in the energy states averaged 88.7 percent of that for all 48 continental states. This proportion rose to 95.4 percent by 1978 and peaked at 96.7 percent by 1981 . By 1987, after energy prices had declined substantially, the average per capita income in energy states declined to 86.8 percent of the average of all states.
Of the 11 energy states, all but Kentucky, Cololado and Wyoming were classifed as downwardly civergent tsee table 4$)^{3.7}$ In half of these eight downwadly divergent states IOklahoma, New Mexico, Louisiana and Texast, relative per capita income fose from 1978 through the early $1980 \mathrm{~s}$, then fell shaply in subsequent years, following energy price trends. Wyoming also exhibited this pattern of growth: its relative per capita income grew to 121 percent of the state avemage by 1980 , remained high in 1981, then plummeted to 89 percent by 1987 . Although classified as downm wardly convergent, Wyoming's per capita income fell below the national average in 1984 and, thus, has contributed to the greater inequality of state income since that year.

In the remaining downwardly divergent enengy states (West Virgina, North Dakota, Utah and Montanal, relative per capita income trended downward throughout the 1978-87 period. Although the fall in energy prices undoubtedy contributed to their slowing after 1981, their sluggish income growth in previous years suggests that other factors were at work as well

The importance of the energy price decline as a contributor to increasing interstate inequality can be seen more clearly by considering the list of downwardly divergent states in table 1. Energy states account for eight of the 10 downwardly divergent states. In addition, Wyoming, has contributed to increasing inequality since 1984.

None of the states with substantial upward movement of relative per capita income were energy-rich states. Instead these states were heavy importers of energy resources who generally benefited from the cheaper energy resources in the 1980s. Since most states with substantial post-1978 income growth had above-average per capita incomes, the fall in energy prices also tended to increase inequality by boosting their growth further above the average. Thus, the de-

\footnotetext{
${ }^{13}$ In the $1947-87$ period, the correlation between relative energy prices and the average relative per capita income of energy states is 0.54 , significantly different from zero at the percent level. The correlation of relative energy prices and the relative per capita income of non-energy states, -0.54 , is identical in absoltte value, but negatively signed. This correlation is also significant at the 1 percent tevel.

14The validity of this classification is suggested by the substantial overtap between this list of energy states and those suggested

1976 (Corrigan and Stantield, 1980). Eight of the 11 states identified as energy states in out study were among the nine continental U.S. states in which of -price declines were associated with declines in total state employment in Brown and Hill (1988).

${ }_{15}$ Research by Hunt (1987) suggests that Colorado's economy was not adversely affected by declining energy prices because of its diversified economic base which captured enough beneficial effects of oll price declines to offset the negative effects.
} in two previous studies. Nine of the 11 states shown in table 4 were among the 10 continental U.S. states with a ratio of energy production to energy consumption greater than unity in 


\section{Chart 3}

\section{Economic Indicators of U.S. Agriculture}

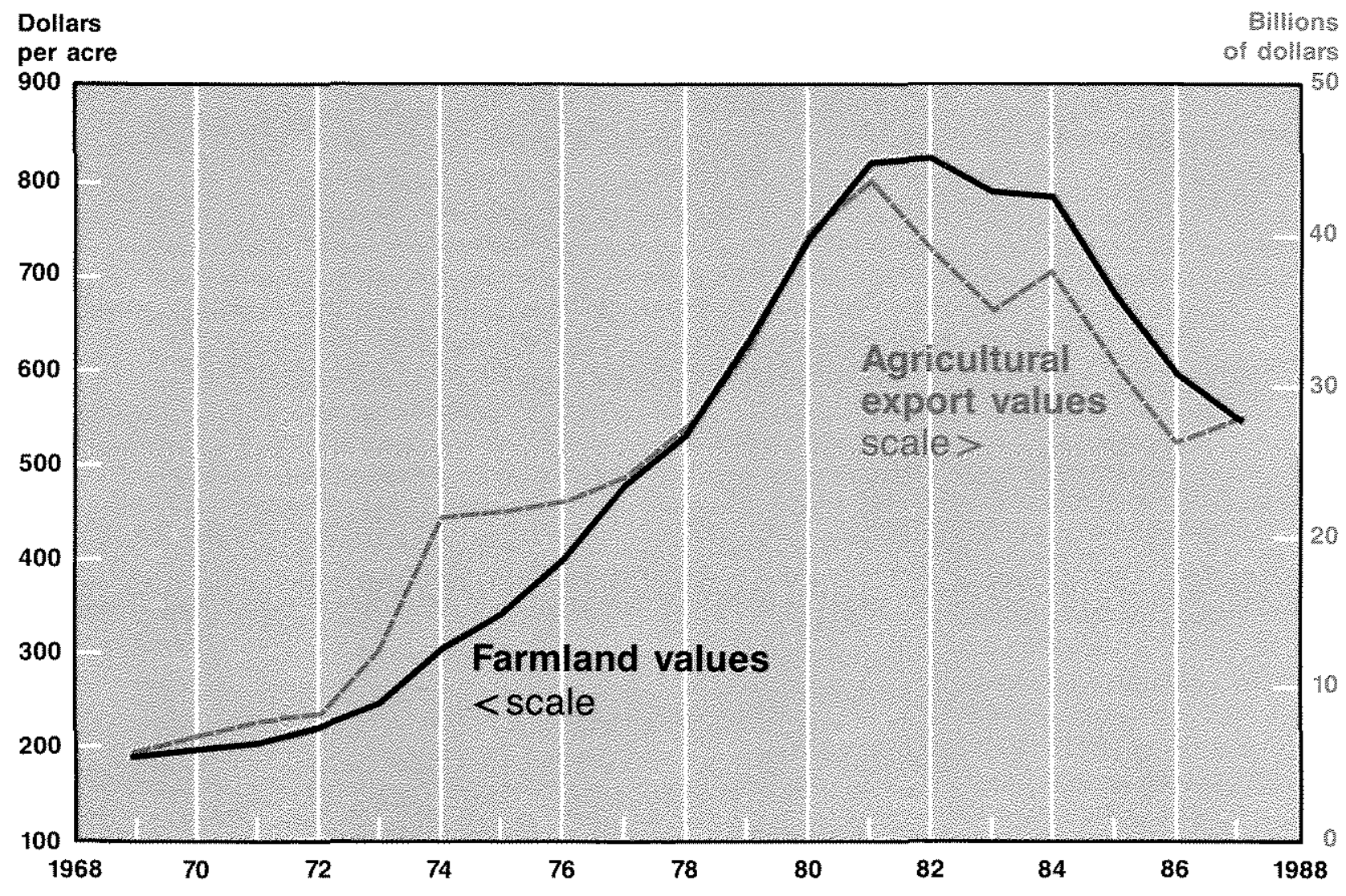

cline in energy prices was an importan factor in increasing inequality in the $1980 \mathrm{~s}^{\text {th }}$

\section{The Influence of the "Farm Crisis"}

The first half of the 1980 s has been accompanied by a widely publicized economic deteriorathon of the nation's agricultural sector ${ }^{17}$ Chart 3 shows two symptoms of the so-called farm crisis. The value of both the nation's farm exports and farmland grew rapidly during the $1970 \mathrm{~s}$ but dem clined during the current decade.

A decline in the farm sector affects non-farm sectors directly linked to agriculture. These include suppliers of fertilizer and farm equipment as well as firms that transport, process and market agriculturat products. Less directy, a decline in farming and agribusiness could adversely affect other sectors as well, such as those providing ser" vices to agricultural workers.

A decline in the nation's agricultural sector would most adversely affect state income in agriculture-inlensive states, One measure of this intensiveness is the proportion of total state earnings accounted for by farm labor and proprietor earnings." Table 5 displays the 12 states that derived at least 4 peecent of their earnings from farms in 1981, the most recent peak in both agricultural exports and farmand values. North $\mathrm{Da}^{\mathrm{a}}$ 1e Ray and Rittenoure (1987) found that dectining energy prices contributed to the increasing inequality of regional per capita income in the 1980s.

"See Petrulis et al. (1987) for a discussion of the reasons for the farm crisis.

${ }^{19}$ Since the purpose of this analysis is to assess the possible effects of the farm sector downturn on state per capita personal income, farm labor and proprietor earnings (a component of personal income) is a more appropriate measure of farm income than net farm income. While real net farm income is a better measure of farm profitabilify, it includes corporate income, which is excluded from the personal income series. 


\section{Table 5}

\section{Impact of Farm States on Inequality}

South Dakola - No Substanial Change North Dakota Downwardy Divegent

lowa 4 Qownwardy Convergent

Nebraska 4 No Substantal Change

ldaho, bownwardy Divergent

A kansas - No Substantial Change

Montana $\longrightarrow$ Downwardy Divergent

Kentucky 4 No Substantal Change

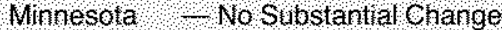

Wisconsin $\neg$ No Substantial Change

Vermont $\neg$ Upward y Convergent

Kansas 4 , No Substantial Change

NOTE farm states are hose in wilch 4 pelcent of nore of total 198 / state earnings were derved trom farming States are ordered from those with the tighest to the lowest percentage

sounce table,

kota and South Dakota were the states most reliant on faming, with 11.9 percent and 15.1 percent of their total earnings directly derived from agriculture.

Average per capita income has declined in farm states relative to nonfarm states since 1978 . Between 1978 and 1987 , relative per capita income in farm states dropped from 97 percent of the aver age to 93 percent. During the same period, the average of relative per capita income in all other states rose from 101 percent to 102 percent.

Despite this divergence, few farm states contributed substantially to interstate income inequality. As lable 5 shows, only three of the 12 farm states - Idaho. Montana and North Dakota - are classified as downwardly divergent. On the other hand, farm states account for two of the 10 convergent states. Relative per capita income also fell substantially in Iowa, a state with aboveaverage per capita income in 1978 , and per capita income rose in Vermont, a state with belowaverage per capita income in 1978. Litle change in relative per capita income occurred in the remaining seven farm states. Overal, the impact of the farm crisis on the recent increase in inequality appears minimal.

\section{CONCUSTON}

The 45-year downward trend in inequality ended in the late 1970 s. Twenty states, evenly divided between below-average and above-average per capita income states, are primarily responsible for the increasing inequality. All slates with aboveaverage per capita income and relatively rapid income growth are located on the Atantic Coast. The states wilh below-average per capita income and relatively slow growth are scattered throughout the nation's interior.

The Sun Betl-Frost Bell deseription of regional growth has limited success in explaming this phenomenon. The shift of manufacturing activity from the Frost Bett to the Sun Belt, which contributed significantly to the narrowing of regional income differentials in the 1970 s, has continued in the 1980 s, but has affected fewer states. Indeed, in reent years, manufacturing has grown relatively rapidly in some New England states, while grow ing no faster than the national average in several Sun Belt states.

The description of the U.S. economy as a bicoastal economy with rapidly growing coastal and slowly growing interior states provides a better insight into the location of states responsible for the rising income inequality, but not necessarily the reasons for this result. The relatively poor performance of the interior states has been attributed to various problems related to agriculture as well as to falling energy prices. The agriculture crisis has little explanatory power. Although the agricultural sector has weakened in the 1980 s, fam states account for only three of the 10 downwadly divergent stales.

On the other hand, declining energy prices have been a major factor in increasing interstate in come inequality. Energy states account for eight of the 10 downwardly divergent states. Another energy state, Wyoming, has contributed to increasing income inequality since 1984.

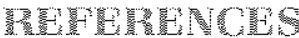

Bradbury, Katharine L., and Lynn E. Browne. "New England Approaches the 1990s," New England Economic Review (January/February 1988), pp. 31-45

Brown, S. P. A., and John K. Hill. "Lower Oil Prices and State Employment," Contemporary Policy Issues (July 1988), pp. $60-68$.

Browne, Lynn E. "Narrowing Regional Income Difterentials," New England Economic Review (September/October 1980), pp. 35-56.

Corrigan, Richard, and Rochelle L. Stanfield. "Rising Energy Prices - What's Good tor Some States is Bad for Others," National Joumal (March 1980), pp. 460-69.

Crandall, Robert W. "The Transformation of U.S. Manufacturing," Industrial Relations (Spring 1986), pp. 18-30. 
"Federal Spending: The Northeast's Loss is the Sunbelt's Gain," National Joumal (Government Research Corporation, June 1976).

Gross, Harold T., and Bernard L. Weinstein. "Frost Belt vs. Sun Belt in Aid Grants: Not a Fair Fight," Wall Street Joumal, August 23, 1988 .

Wunt, Gary L. "The Impact of OI Price Fluctuations on the Economies of Energy Producing States," Review of Regional Studies (Fall 1987) pp. 60-76.

Manuel, David P. "The Effects of Higher Energy Prices on State Income Growth," Growth and Change (July 1982). pp. 26-37.

Miernyk, William H. "Rising Energy Prices and Regional Economic Development," Growth and Change (July 1977), pp. $2-7$.

Petrulis, Mindy, Bernal L. Green, Fred Hines, Richard Nolan and Judith Sommer. How is Farm Financial Stress Affecting Rural America? Agricultural Economic Report Number 568, U.S. Department of Agriculture (June 1987).

Ray, Cadwell $L$., and R. Lymn Rittenoure. "Recent Regional Growth Patterns: More inequality, "Economic Development Quarterly (August 1987), pp. 240-48.

Reich, Robert B. "The Rural Crisis, and What to Do About it," Economic Development Quarterly (Febtuary 1988), pp. 3-8.

Schmidt, Ronald H. "Oil and the Economy," Federal Reserve Bank of San Francisco Weekly Letter (May 27, 1988).
Shapiro, S. S., and M. B. Wikk. "An Analysis of Variance Test for Normality (complete samples)." Biometrika (Volume 52, $1965)$, pp. $591-611$.

"The Second War Between the States." Business Week (May 17, 1977).

U.S. Congress, Joint Economic Committee. "The Bi-Coastal Economy: Regional Patterns of Economic Growth During the Reagan Administration," Staff Study by the Democratic Staff, mimeo (July 1986).

U.S. Department of Commerce. "Regional Differences in Per Capita Personal income Widen in the 1980s. " Commerce News (August 20, 1987).

Weinstein, Bernard L., and Harold T. Gross. "The Rise and Fall of Sun, Rust, and Frost Belts." Economic Development Quarterly (February 1988), pp. 9-18.

Weinstein, Bernard L., Harold T. Gross, and John Rees. Regional Growth and Decline in the Unifed States, Ind ed. (Praeger Publisters, 1985).

Wiliamson, J.G. "Regional inequality and the Process of National Development: A Description of the Patterns." ECOnomic Development and Cultural Change (July 1965), pp. 3-83.

Yotopotios, Pan A., and Jeffrey B. Nugent. Economics of Development: Empirical Investigations (Harper \& Row, 1976). 